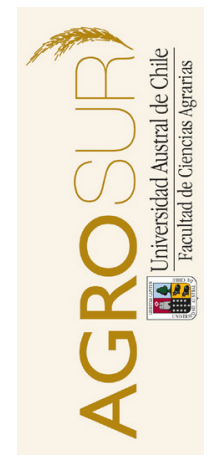

\title{
Creación de praderas diversas para servicios multi-ecosistémicos: un ejemplo de políticas de esquemas agro-ambientales impulsados por la ciencia en Reino Unido
}

\author{
Creating productive diverse grassland for multi-ecosystem services: an example \\ of agri-environment schemes policies driven by science in United Kingdom
}

\author{
Beaumont, D.A. ${ }^{a}$, Griffith, B.A. ${ }^{a}$, Dunn, R.M. ${ }^{a}$, Orr, R.J. ${ }^{a}$, Rivero, M.J. ${ }^{a *}$, \\ Woodcock, B. ${ }^{b}$, Pywell, R. ${ }^{b}$, Tallowin, J.R.B. ${ }^{a}$
}

\author{
${ }^{a}$ Rothamsted Research, North Wyke, Okehampton, Devon EX20 2SB, UK. \\ ${ }^{b}$ Centre for Ecology and Hydrology, Wallingford, Oxfordshire OX10 8BB, UK.
}

A RT I C LE INFO

\begin{tabular}{l}
\hline Article history: \\
Received: 25.04 .2018 \\
Accepted: 07.08.2018 \\
\hline View Point, \\
Special Issue: Agroecology and \\
Sustainable Agricultural Systems \\
\hline *Corresponding author: \\
Jordana Rivero \\
E-mail address: \\
jordana.rivero-viera@rothamsted.ac.uk
\end{tabular}

\section{INTRODUCTION}

Grassland accounts for $72 \%$ of agricultural land use in the UK and constitutes the largest area of habitat managed under the agri-environment schemes (DEFRA, 2016). Most agricultural grassland is intensively managed resulting in floristically species-poor swards supporting a restricted range of invertebrates and grassland agri-environment schemes have had a limited effect in diversifying these homogeneous habitats.

Increasing grassland plant diversity can potentially provide multiple benefits including greater productivity and forage quality, increased faunal abundance and diversity, improve soil structure, and reduce erosion and flood risk (Puttock and Brazier, 2014). Floristically diverse grasslands also have the potential to be more resistant to drought. Legumes in swards can help mitigate climate change and acidification and eutrophication of rivers and land by reducing the need for nitrogen fertiliser (Crews and Peoples, 2004).

Restoration research has primarily focused on the remaining fragments of species-rich grassland. Since conventionally managed grasslands cover a large proportion of the landscape in the UK, modest increases in plant diversity via agri-environment schemes (AES) could have an extensive impact on the environment as previously suggested by De Deyn et al. (2011) who found that long-term biodiversity restoration practices increased soil C and $\mathrm{N}$ storage. Therefore, in order to devise new agri-environment schemes to enhance biodiversity and ecosystem services, i.e., the benefits people obtain from ecosystems, an experiment was established by Rothamsted Research and the Centre for Ecology and Hydrology in Devon (UK), funded by the Department for Environment, Food and Rural Affairs (DEFRA), to develop and test simple, widely available, low-cost seed mixes under different managements in improved grassland. A "sister" site with a similar design was established in Berkshire (Woodcock et al., $2012,2013,2014$ ), and both experiments provided the evidence base for an AES option.

\section{EXPERIMENTAL APPROACH}

Plant species were selected on the basis of their multifunctional characteristics including their ability to establish in fertile soils, agronomic value, potential for soil restructuring and numbers of associated insects and birds (for the full list of plant species see Appendix 1 in Woodstock et al., 2012). The field experiment was established in 2008 at North Wyke, Devon, UK on an agriculturally improved, species-poor grassland on clay soil of moderately high fertility (phosphorous index >2) and finished in 2012.

A nested randomised block design with four replicates was used to investigate the effects of three seed mixtures, subsequent management of the sward, the intensity of management and the seed bed preparation on biodiversity and a range of ecosystem services, namely: pollinators abundance, carbon sequestration, etc. Hence, a wide range of biological, biophysical and agronomic variables were measured for four successive years after sward establishment.

The three sown seed mixes were: 1 ) grass only $(G)$ comprising five species; 2) grass + legume (GL) comprising five grasses and seven agricultural legumes; 3 ) grass + legume + non-legume forb (GLF) comprising five grasses, seven agricultural legumes and six nonlegume forbs. In addition, there was an unsown 'ori- 
ginal grassland' permanent pasture control with four replicates.

Each seed mix treatment was split into two different management sub-plots. Management regimes were either grazed by beef cattle or cut, each being further split into without (typical management) or with (extensive management) an eight-week rested period in mid-summer to provide nectar, pollen and seed resources and habitat for fauna. Grazed plots were 0.1 ha and cut plots $0.07 \mathrm{ha}$.

The seed beds were established either by conventional ploughing following a herbicide application (P) or minimal cultivation (MC) by harrowing to a depth of $5 \mathrm{~cm}$ creating $40-50 \%$ bare ground. Only control plots received inorganic fertiliser (50 kg N ha-1) each spring.

\section{OVERVIEW OF OUR PRINCIPAL FINDINGS}

- Ploughing achieved a greater establishment of sown species compared with MC highlighting how the established competitive species can impose a constraint for emerging seedlings hindering restoration in improved grasslands. This agrees with the findings of Pywell et al. (2010) who reported an increase in cover of grasses and non-legume forbs following herbicide application and deep cultivation.

- Minimal cultivation used in conjunction with herbicide could potentially improve seedling recruitment.

- The cutting management enhanced legume and forb cover in the establishment year compared with grazing management suggesting preferential grazing of these plant groups, and coinciding with the pattern reported by Pywell et al. (2010) who observed that cutting increased cover of legumes and non-legumes compared with grazing. The cutting management continued to support higher forb abundance in subsequent years than grazing whereas the reverse occurred for legume persistence. The cover of legumes decreased over the four-year period, whereas forb cover increased in the second year before declining.

- Peak herbage DM yield occurred in the first year (2009) where both legumes and forbs were included in the mix in the typically managed ploughed treatments, evidence of increased diversity causing overyielding as suggested by Tilman et al. (2006) who found that greater diversity leads to overyielding in grasslands. In 2009 the typically managed ploughed GLF plots produced $50 \%$ more total DM yield than the equivalent 'grass only' plots. However, on the second year, yield in GLF plots dramatically declined by $31 \%$ reflecting reduced legume abundance. The sown legumes and some of the forbs were agricultural cultivars which may have selection trade-offs between productivity and longevity. This result illustrates that to maintain diverse swards, associated productivity and other ecosystem services benefits a viable AES would have to include an option to re-sow.

- The inclusion of legumes and forbs in seed mixes enhanced flower density which boosted total pollinator (bees, butterflies and hoverflies) abundance. A similar result was obtained at the "sister" experiment at Berkshire (Woodcock et al., 2014). Beetle biomass, an indicator of potential food availability for insectivorous birds was also positively associated with more diverse swards.

- Both pollinators and beetle biomass declined over the four-year period in response to the reduction in legume and forb cover. Beetle biomass and winter seed resources for birds and insects were both enhanced when swards were rested in mid-summer as shown by Woodcock et al. (2013).

- This study demonstrated that a resting period from cutting and grazing during the mid-summer has important beneficial effects on enabling plants to reach full phenological development and that the lack of disturbance provided suitable conditions for beetle populations to increase. Although pollinators did not benefit from a rested management at North Wyke site, less intensive management coinciding with peak pollinator activity could benefit pollinator abundance and species richness as observed demonstrated at the "sister" experiment at Berkshire (Woodcock et al., 2014).

- The study also demonstrated that it is possible to achieve modest enhancement of plant diversity with associated positive effects on a variety of ecosystem services using inexpensive, simple seed mixes and management techniques in lowinput grasslands.

- Total Carbon and Total Nitrogen in the top $7.5 \mathrm{~cm}$ of soil were influenced by seed bed preparation with higher concentrations under $\mathrm{MC}$ relative to ploughing which inverts the topsoil.

- Following the cessation of inorganic fertiliser applications soil total phosphorus (TP) levels declined over time. Higher levels of TP were found under grazing compared with the cutting management.

\section{IMPLICATIONS AND DEVELOPMENT OF POLICIES}

Results from this study, in conjunction with the Berkshire site results, facilitated the development of 
inexpensive and practicable AES legume and forbs-rich swards options within the Environmental Stewardship Scheme (ES) in 2013 (EK21; EFTEC, 2015). The ES scheme was superseded in 2015 by the Countryside Stewardship Scheme (CS) however, there are currently 145 active ES agreements which include legume and herb-rich sward options covering 1,640.64 ha (Natural England, 2018) ${ }^{1}$.

The CS scheme has two options derived from the results of this experiment; GS4: Legume and herb-rich swards for conventional farms and OP4: Multi-species ley for organic farms. Both of these options prescribe the use of simple GLF seed mixes, prohibit the use of inorganic nitrogen fertilisers, can be managed by cutting or grazing and have a rested management in summer. It is permitted in option GS4 to re-sow the sward or move to a different area to compensate for poor agricultural cultivar persistence.

In April 2018 there were 269 active CS agreements which include 239 agreements in option GS4, with $2,072.61$ ha being managed under that option, and 30 agreements in option OP4, covering 267.38 ha. Uptake of these options demonstrate that is feasible to achieve wide-scale enhancement of biodiversity whilst supporting commercial livestock production by creating low cost multifunctional grasslands.

\section{ACKNOWLEDGEMENTS}

This project was funded by DEFRA (project BD1466 \& BD5208). Support in writing up this note was greatly received by the Biotechnology and Biological Sciences Research Council (BBSRC) and the Natural Environment Research Council (NERC) through the strategic programme Achieving Sustainable Agricultural Systems (ASSIST; BBS/E/ C/000I0130 and NE/N018125/1).

\section{REFERENCES}

Crews, T.E., Peoples, M.B., 2004. Legume versus fertilizer sources of nitrogen: ecological tradeoffs and human needs. Agriculture, Ecosystems and Environment 102(3), 279-297. https://doi.org/10.1016/j.agee.2003.09.018

De Deyn, G.B., Shiel, R.S., Ostle, N.J., McNamara, N.P., Oakley, S., Young, I., Freeman, C., Fenner, N., Quirk, H., Bardgett,
R.D., 2011. Additional carbon sequestration benefits of grassland diversity restoration. Journal of Applied Ecology 48(3), 600-608. https://doi.org/10.1111/j.13652664.2010.01925.x

Department for Environment, Food and Rural Affairs (DEFRA), 2016. Agriculture in the United Kingdom 2015. DEFRA, UK, 106 p. https://assets.publishing.service. gov.uk/government/uploads/system/uploads/attachment_data/file/557993/AUK-2015-05oct16.pdf

Economics for the Environment Consultancy Ltda. (EFTEC), 2015. The economic case for investment in natural capital in England: land use appendix. Final report. http:// nebula.wsimg.com/762965c22588fbc21a8ccafe26828 5fe?Access KeyId=68F83A8E994328D64D3D\&dispositi on=0\&alloworigin=1 (access, 06.08.2018).

Natural England, 2018. https://www.gov.uk/government/ organisations/natural-england (access, 01.04.2018).

Puttock, A., Brazier, R., 2014. Culm grasslands proof of concept phase 1: Developing an understanding of the hydrology, water quality and soil resources of unimproved grasslands. University of Exeter, Devon, UK, 65 p. https://www.devonwildlifetrust.org/sites/default/files/2018-01/Culm-Proof-of-Concept.pdf

Pywell, R.F., Woodcock, B.A., Orr, R., Tallowin, J.R.B., McEwen, I., Nowakowski, M., Bullock, J.M., 2010. Options for wide scale enhancement of grassland biodiversity under the Entry Level Scheme. Aspects of Applied Biology 100, 125-132.

Tilman, D., Reich, P.B., Knops, J.M.H., 2006. Biodiversity and ecosystem stability in a decade-long grassland experiment. Nature 441, 629-632. https://doi.org/10.1038/ nature 04742

Woodcock, B.A., Bullock, J.M., Nowakowski, M., Orr, R., Tallowin, J.R.B., Pywell, R.F., 2012. Enhancing floral diversity to increase the robustness of grassland beetle assemblages to environmental change. Conservation Letters 5(6), 459-469. https://doi.org/10.1111/j.1755263X.2012.00262.X

Woodcock, B.A., Savage, J., Bullock, J.M., Nowakowski, M., Orr, R., Tallowin, J.R.B., Pywell, R.F., 2013. Enhancing beetle and spider communities in agricultural grasslands: the roles of seed addition and habitat management. Agriculture, Ecosystems and Environment, 167, 79-85. https:// doi.org/10.1016/j.agee.2013.01.009

Woodcock, B.A., Savage, J., Bullock, J.M., Nowakowski, M., Orr, R., Tallowin, J.R.B., Pywell, R.F., 2014. Enhancing floral resources for pollinators in productive agricultural grasslands. Biological Conservation 171, 44-51. https:// doi.org/10.1016/j.biocon.2014.01.023

\footnotetext{
${ }_{1}^{1}$ Natural England, 2018. Personal communication.
} 
